\title{
KOMPETENSI PERAN CUSTOMER SERVICE DALAM MENDUKUNG PELAYANAN KEPADA KONSUMEN
}

\author{
Dedi Rianto Rahadi ${ }^{\otimes}$ Alda Amelia Majid ${ }^{\otimes 2}$ \\ 1,2Program Studi Manajemen,President University, Cikarang Utara, Indonesia, 17550

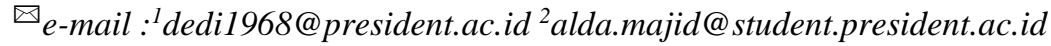

\begin{abstract}
Competition in the business world is increasing, therefore companies must have quality human resources. In the company, every employee must have competency standards that aim to determine the quality of service in the eyes of consumers in determining the strategy required for customer service. The purpose of this study was to determine and analyze how competence in the role of customer service in improving service. This research method is descriptive qualitative, namely research using descriptive by applying a review of several case study methods and based on previous literature reviews by experts

The results of research carried out based on previous literature and the opinions of several experts processed by researchers, the result is that competence has a very important role for customer service in improving service
\end{abstract}

Keywords : competence, the role of customer service, service

\begin{abstract}
Abstrak
Persaingan dalam dunia bisnis semakin meningkat, maka dari itu perusahaan harus memiliki sumber daya manusia yang berkualitas. Dalam perusahaan setiap karyawan harus memiliki standar kompetensi yang bertujuan untuk menentukan kualitas pelayanan dimata konsumen dalam menetapkan strategi nya dibutuhkan customer service. Tujuan penelitian ini untuk mengetahui dan menganalisis bagaimana kompetensi pada peran customer service dalam meningkatkan pelayanan. Metode penelitian ini yaitu deskriptif kualitatif yaitu penelitian dengan menggunakan deskriptif dengan menerapkan review dari beberapa metode studi kasus dan berdasarkan literatur review sebelumnya oleh para ahli. Hasil penelitian yang dilakukan berdasarkan literatur terdahulu dan pendapat beberapa ahli yang diolah peneliti, hasilnya bahwa kompetensi memiliki peran yang sangat penting bagi customer service dalam meningkatkan pelayanan
\end{abstract}

Kata kunci : kompetensi, peran customer service, pelayanan

\section{Pendahuluan}

\section{Latar belakang}

Sumber daya manusia merupakan aset yang penting dalam menjalankan bisnis. Dalam pelaksanaan bisnis, pelayanan merupakan sesuatu yang harus dimiliki oleh perusahaan agar dapat bersaing dengan perusahaan lainnya. Apalagi perusahaan pada sektor jasa.
Kualitas sumber daya manusia yang ada pada perusahaan harus diperhatikan, bahkan terkadang perusahaan memberikan pelatihan yang berkelanjutan terhadap karyawannya agar kualitas nya tetap terjaga dan bertujuan untuk pengembangan kompetensi walaupun telah menjadi karyawan dalam jangka yang lama. Sumber daya manusia berperan dalam menyampaikan 
penawaran tentang jasa perusahaannya kepada para klien atau pelanggan jasa. Perusahaan pada sektor produk berbeda dengan perusahaan yang menawarkan jasa, dimana pada perusahaan jasa dituntut untuk memberikan pelayanan yang berkualitas sehingga harus mengoptimalkan bagian customer service nya untuk membentuk persepsi perusahaan yang baik di pikiran konsumen nya (Kasmir, 2017:249). Dalam perusahaan juga setiap karyawan harus memiliki standar kompetensi yang bertujuan untuk menentukan kualitas pelayanan dimata konsumen. Standar kompetensi digunakan untuk menentukan pelaksanaan terhadap pelayanannya. Menurut Moeheriono (2016:5) mengatakan bahwa kompetensi merupakan suatu karakteristik yang berhubungan dengan efekrifitas pada kinerja suatu individu dalam bekerja yang dijadikan sebagai acuan sehingga memiliki kinerja yang unggul di dalam organisasi. Apabila perusahaan telah menerapkan sandar kompetensi bagi karaywannya maka akan tercipta pelayanan prima (service exellent). Dengan kualitas pelayanan yang baik maka akan terjalin hubungan jangka panjang konsumen terhadap perusahaan karena merasa puas dan sesuai harapan konsumen. Untuk perusahaan jasa, tantangan bagi pihak perusahaan khususnya manajemen jasa nya yaitu menyajikan standar pelayanan sehingga dalam menetapkan strategi nya dibutuhkan customer service. Customer service merupakan kegiatan yang bertujuan untuk memberikan pelayanan agar konsumen puas dan melakukan interaksi pula kepada konsumen maupun calon konsumen mengenai jasa atau produk yang ditawarkan. Customer service berperan memberikan pelayanan serta menjadi jembatan untuk menghubungkan masyarakat dengan perusahaan. Menurut Tjiptono (2016:59) bahwa dalam pelayanan agar kepuasan terpenuhi, dengan menawarkan keunggulan yang dapat memenuhi kebutuhan konsumen nya.Seorang customer service diharapkan dapat memcahkan masalah serta keluhan yang dilontarkan oleh konsumen dan memberikan informasi secara mendetail mengenai soluasi dari permasalahan konsumen. Customer service merupakan orang-orang yang terlibat dalam perusahaan yang mampu mengembangkan pelayanan yang prima dan memberi perhatian kepada konsumen (Kasmir, 2015). Hal ini mencerminkan sikap perusahaan kepada konsumen sehingga apabila konsumen memberi respon yang baik akan menguntungkan perusahaan. Baik dan buruknya pelayanan yang diberikan pada konsumen akan membentuk persepsi yang berbedabeda pada setiap konsumen.

Dengan persaingan dunia bisnis yang semakin ketat, perusahaan khususnya di bidang jasa harus meningkatkan pelayanan pada customer service nya sehingga akan tercapai kinerja pelayanan perusahaan yang baik dan didukung juga oleh kompetensi para karyawannya. Hal ini sesuai dengan penelitian oleh Hutabalian (2015) yang hasilnya bahwa customer service berperan penting untuk meningkatkan mutu layanan terhadap konsumen. Selain itu penelitian Kristiana (2018) yang menyatakan bahwa standar kompetensi berperan untuk memberikan pelayanan atau sevice officer dan dengan standar kompetensi yang baik akan memberikan pelayanan yang prima.Selain itu menurut penelitian oleh Wulandari (2016) bahwa standar kompetensi memiliki pengaruh terhadap kualitas pelayanan yang diberikan perusahaan.

Sesuai dengan latar belakang, peneliti akan melakukan penelitian lebih lanjut yang berjudul "Kompetensi Peran Customer Service dalam Mendukung Pelayanan Kepada Konsumen" 


\section{Rumusan Masalah}

Rumusan masalah dalam penelitian ini adalah bagaimana kompetensi peran customer service dalam mendukung pelayanan kepada konsumen.

\section{Tujuan Penelitian}

Tujuan Umum

Memenuhi tugas mata kuliah competency based human capital dan mengetahui kompetensi peran customer service dalam mendukung pelayanan kepada konsumen.

\section{Tujuan Khusus}

Untuk mengetahui dan menganalisis bagaimana kompetensi peran customer service dalam mendukung pelayanan kepada konsumen.

\section{Metode Penelitian}

Metode penelitian ini yaitu deskriptif kualitatif yaitu penelitian dengan menggunakan deskriptif dengan menerapkan review dari beberapa metode studi kasus dan berdasarkan literatur review sebelumnya oleh para ahli. Penelitian Kualitatif merupakan penelitian yang menekankan dalam makna, konsep, gejala, karakteristik mengenai suatu fenomena dengan berbagai cara yang disajikan secara naratif.

Tujuan dari penelitian kualitatif yaitu untuk mengetahui jawaban mengenai fenomena maupun pertanyaan yang disertai prosedur secara ilmia dengan disusus sistematis menggunakan pendekatan kualitatif (Sugiyono, 2016). Selain itu dilakukan literatur study (desk reseacrh) yaitu dengan cara mencari serta menghimpun data dari berbagai referensi yang berkaitan dengan topik atau studi penelitian yang sedang diteliti. Penelitian desk research biasanya dapat dilakukan pada tempat pribadi bahkan hanya di meja kerja tanpa berpindah kemanapun. Desk research juga meliputi kegiatan studi pustaka atau literatur, pengolahan maupun analisis data.
Sumber datanya diperoleh dari data sekunder dengan cara membaca, mengutip, dan menelaah suatu data terkait. Data sekunder merupakan data yang tidak secara langsung diberikan pada pengumpul data, seperti orang lain ataupun dokumen (Sugiyono, 2016:137). Dalam penelitian ini literatur yang digunakan yaitu yang berkaitan dengan management human capital khususnya yang berkaitan dengan kompetensi peran customer service dalam mendukung pelayanan kepada konsumen.

\section{Hasil}

Hasil penelitian yang dilakukan berdasarkan literatur terdahulu dan pendapat beberapa ahli yang diolah peneliti, hasilnya bahwa kompetensi memiliki peran yang sangat penting bagi customer service dalam meningkatkan pelayanan. Hal ini juga sejalan dengan penelitian Hutabalian (2015) yang hasilnya bahwa customer service berperan penting untuk meningkatkan mutu layanan terhadap konsumen. Selain itu penelitian Kristiana (2018) yang menyatakan bahwa standar kompetensi berperan untuk memberikan pelayanan atau sevice officer dan dengan standar kompetensi yang baik akan memberikan pelayanan yang prima.

\section{Pembahasan}

Sumber Daya Manusia merupakan sekumpulan orang yang berada pada suatu organisasi yang memberikan sumbangan baik pemikiran maupun tenaga untuk mencapai tujuan dari organisasi tersebut dengan cara melakukan berbagai macam kegiatan maupun aktivitas di dalam nya. Dalam hal ini, sumber daya manusia bukan hanya terbatas pada ahli atau yang berpengalaman saja, melainkan semua orang tenaga kerja atau karyawan yang ada pada perusahaan tersbut terlibat (Sadono, 2016:172). Sedangkan menurut Hasibuan (2017:10) menyebutkan bahwa 
sumber daya manusia merupakan suatu hal yang didalam nya berisi peranan dari tenaga kerja atau karyawan dalam suatu organisasi yang memiliki peran untuk terwujudnya tujuan yang efektif dan menguntungkan. Seluruh potensi yang dimiliki oleh sumber daya manusia dapat berpengaruh terhadap segala upaya dalam organisasi untuk pencapaian tujuan

Dalam perusahaan juga setiap karyawan harus memiliki standar kompetensi yang bertujuan untuk menentukan kualitas pelayanan dimata konsumen. Standar kompetensi digunakan untuk menentukan pelaksanaan terhadap pelayanannya. Menurut Wibowo (2016:271) bahwa kompetensi merupakan kemmapuan dalam hal melakukan kegiatan atau pekerjaan yang didukung dengan pengetahuan serta sikap yang berkaitan terhadap pekejaan nya

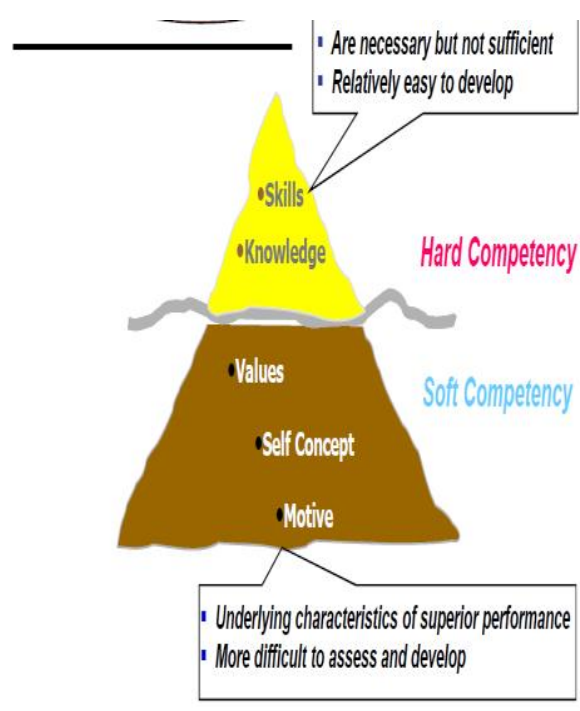

Gambar 1. Makna Kompetensi

Menurut Spencer dalam Moeheriono (2016:5) mengatakan bahwa kompetensi merupakan karakterisitik yang menjadi dasar perilaku atas gambaran motif karakteristik pribadi dalam diri terhadap nilai mengenai pengetahuan yang memiliki kinerja yang unggul di dalam organisasi. Selain itu terdapat karakteristik mengenai kompetensi yaitu knowledge atau pengetahuan, skill atau keterampilan, konsep atau nilai diri (selfconcept) yang berdasarkan pada nilai diri seseorang, dan karakteristik pribadi (trait) yang konsisten terhadap tanggapan dan tenang apabila ada tekanan.

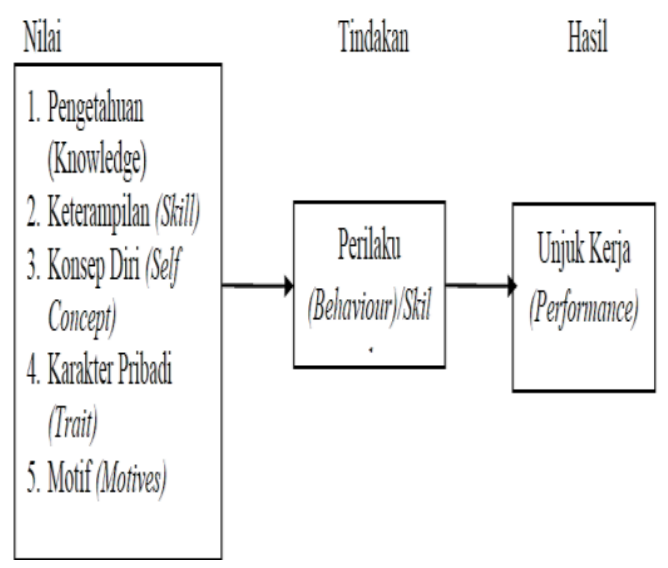

Gambar 2. Komponen Kompetensi

Sedangkan menurut Wahyudi (2015:1058) melakukan penelitian bahwa kompetensi merupakan kemampuan yang bertujuan untuk melaksanakan pekerjaan yang dilandasi oleh pengetahuan serta sikap yang tertanamn untuk merujuk pada pekerjaan yang bercirikan suatu profesionalisme. Pentingnya kompetensi pada suatu organisasi yaitu untuk menciptakan kinerja pegawai sehingga dapat mencapai tujuan pada organisasi. Perusahaan pada sektor produk berbeda dengan perusahaan yang menawarkan jasa, dimana pada perusahaan jasa dituntut untuk memberikan pelayanan yang berkualitas sehingga harus mengoptimalkan bagian customer service nya untuk membentuk persepsi perusahaan yang baik di pikiran konsumen nya (Kasmir, 2015:249).

Customer service merupakan orang-orang yang terlibat dalam perusahaan yang mampu mengembangkan pelayanan yang prima dan memberi perhatian kepada konsumen (Alma, 2016). Menurut Kasmir (2015:208) bahwa customer service berperan sebagai pemberi layanan, mempertahankan konsumen agar setia 
menggunakan produk atau jasa pada perusahaan, meyakinkan konsumen bahwa produk atau jasa yang ditawarkan kepada konsumen memiliki kualitas yang baik. Sedangkan menurut Pahlijan (2017) bahwa customer service berkaitan dengan kebijakan serta pelaksanaan untuk melayani konsumen yang bertujuan memberikan kepuasan mengenai pelayanan yang diberikan.

Tugas-tugas dari customer service sebagai berikut :

a. Memberikan perhatian kepada konsumen yang datang ke perusahaan

b. Memberikan informasi mengenai manfaat jasa atau produk kepada konsumen dan calon konsumen. Pada hal ini brosur dan formulir dibutuhkan untuk kelancaran pemberian informasi

c. Pendekatan kepada konsumen untuk menggunakan produk atau jasa

d. Bersedia menangani keluhan dan permasalahan yang dihadapi oleh konsumen yang apabila terselesaikan dapat menjadi tolak ukur dalam penilaian kinerja dalam perusahaan

e. Sebagai customer relation, dimana menjadi penghubung antara perusahaan dengan konsumennya

f. Menjaga hubungan baik antara perusahaan dengan konsumen dan menjadi sarana konsultasi sehingga memberikan kemudahan pada konsumen

Terdapat beberapa kriteria yang menjadi tolak ukur untuk dalam penilaian pelayanan yang prima yaitu

a. Kemampuan

Dalam hal ini kemampuan terdiri dari pengetahuan serta keterampilan yang berguna untuk mendukung program kerja yang dilaksanakan pada perusahaan

b. Sikap
Siap merupakan perilaku yang dipraktekan saat menghadapi konsumen

c. Penampilan

Dengan penampilan yang baik akan menciptakan presepsi kepercayaan dari konsumen terhadap perusahaan

d. Perhatian

Dalam hal ini perhatian merupakan rasa peduli terhadap konsumen ang berkaitan dengan keinginan, saran serta kritik yang diberikan pada perusahaan

e. Tindakan

Bertujuan untuk melakukan berbagai attivitas atau kegiatan seperti melayani konsumen

f. Tanggung jawab

Dalam hal ini tanggung jawab merupakan sikap yang berpihak kepada konsumen sebagai wujud dari kepedulian sehingga akan mempekecil kerugian maupun ketidakpuasan dari konsumen.

Terdapat beberapa fator yang mempengaruhi kualitas pelayanan yaitu:

1. Kualitas internal yang terdiri dari beberapa hal :

a. Pola manajemen umus

b. Penyedia menenai fasilitas pendukung

c. Keselarasan hubungan sesama karyawan pada organisasi

d. Pola yang intensif

2. Kualitas eksternal yang terdiri dari beberapa hal :

a. Pola mengenai tatacara dalam penyediaan jasa

b. Pola layanan pada bidang distribusi

c. Pola pengadaan barang atau jasa yang berkualitas

Dalam perusahaan juga setiap karyawan harus memiliki standar kompetensi yang bertujuan untuk menentukan kualitas pelayanan dimata 
konsumen. Menurut Sydarso (2016L57) bahwa kualitas pelayanan memiliki hubungan dengan kepuasan pelanggan sehingga akan memberi rangsangan mengenai ikatan yang menguntungkan antara perusahaan dengan konsumen dalam jangka waktu yang lama .Menurut Fisqiyah (2015:125) kualitas pelayanan adalah suatu hal yang memberikan dorongan pada konsumen untuk memiliki hubungan yang baik dengan perusahaan dalam jangka waktu yang panjang dengan cara perusahaan memberikan kebutuhan konsumen dengan baik. Pelayanan merupakan tindakan atau perbuatan seseorang terhadap organisasi dalam rangka memberikan kepuasan pada konsumen. Menurt Parasuraman (2016) bahwa dalam suatu pelayanan didasarkan pada beberapa hal, yaitu evaluasi mengenai kualitas pelayanan yang diberikan, persepsi konsumen terhadap pellayanan, dan proses pelayanan dalam penyampaian pada konsumen. Sedangkan menurut Tjiptono (2018:157) bahwa dalam kualitas layanan terdapat beberapa faktor yang mempengaruhi, yaitu expected service dan perceived service. Apabila suatu layanan diterima dan sesuai dengan ekspetasi maupun harapan konsumen, maka dikatakan bahwa jasa tersebut positif. Apabila perceived service bisa melampaui expected service maka kualitas layanan dianggap tidak baik. Maka dari itu baik maupun tidak nya pelayanan ditentukan dari apakah perusahaan dapat memenuhi kebutuhan konsumen dan respon yang diberikan konsumen pada perusahaan. Sedangkan menurut Kotler dan Keller (2016:55) mengatakan bahwa dalam kualitas pelayanan yang ditawarkan oleh perusahaan pada dasarnya merupakan sesuatu yang tidak berwujud namun saling melengkapi anatara satu pihak dan pihak lainnya. Sedangkan menurut Rusydi (2017:39) bahwa kualitas pelayanan dapat dikatakan sebagai tingkat mengenai keunggulan yang diharapkan oleh konsumen sehingga perusahaan harus memberikan yang terbaik karena akan dijadikan dasar dalam penilaian konsumen terhadap barang atau jasa nya.

Menurut Rangkuti (2017:45) terdapat beberapa indikator kalitas pelayanan yaitu :
a. Hubungan dari faktor kualiatas pelayanan dan kepuasan konsumen
b. Service quality
c. Tangibility
d. Marketing Communication
e. Pricing

Menurut Tjiptono (2020:182) terdapat beberapa strategi yang dapat meningkatkan kualitas pelayanan, yaitu :

1. Mengidentifikasi mengenai determinasi dalam kualitas layanan, Seorang karyawan diwajibkan dapat menawarkan layanan yang berkualitas kepada calon konsumen dan konsumen. Faktor yang menjadi penilaian nya contohnya kemanan saat transaksi,dan lainnya

2. Mengidentifikasi ekspektasi konsumen, perusahaan memiliki cara tersendiri untuk menarik minat konsumen. Semakin banyak janji yang ditawarkan oleh perusahaan maka akan semaking tinggi pula ekspektasi yang diharapkan oleh konsumen. Maka dari itu perusahaan harus berhatihati saat memberikan janji pada konsumen.

3. Memberikan bukti terhadap kualitas layanan nya. Hal ini bertujuan untuk memperkuat penilaian dari konsumen baik sebelum maupun sesudah layanan tersampaikan

4. Mendidik konsumen mengenai layanan perusahaan. Dalm hal ini maksudnya untuk mewujudkan suatu proses penyampaian yang efektif sehingga mudah dalam memahami nya. 
Pelayanan yang prima (service exellent) merupakan suatu sikap karyawan untuk melayani para konsumen. Terdapat beberapa unsur untuk mewujudkan pelayanan prima yaitu keramahan, kecepatan, ketepatan, dan kenyamanan. Apabila keempat unsur tersebut ditrapkan dalam pelayanan kepada konsumen, maka akan terwujud pelayanan prima yang akan membuat para konsumen puas. Untuk mewujudkannya, karyawan perusahaan juga harus memiliki kemampuan maupun skil yang bagus seperti berpenampilan yang menarik, selalu siap untuk melayani konsumen, dan menangani berbagai keluhan yang diminta konsumen. Karyawan juga harus menjunjung tinggi profesionalitas dan membina hubungan baik kepada konsumen perusahaan. Untuk membuktikan apakah organisasi telah memiliki pelayanan yang baik, menurut Winowtan (2020) ada beberapa tahapannya yaitu memberikan sikap yang positif kepada konsumen, mengetahui dan melakukan identifikasi kebutuhan konsumen, mengaplikasikan atau mempraktekan yang sesuai dengan kebutuhan kosnumen, dan adanya pengakuan terhadap layananproduk atau jasa dari konsumen.

Sumber daya manusia dapat berpengaruh terhadap segala upaya dalam organisasi untuk pencapaian tujuan. Dengan dasar teori dari berbagai literatur, baik jurnal maupun buku. Sebagian besar teori tersebut memiliki hasil bahwa ada keterakiatan antara motivasi kerja dengan kinerja karyawan. penelitian oleh Hutabalian (2015) yang haslnya bahwa customer service berperan penting untuk meningkatkan mutu layanan terhadap konsumen. Selain itu penelitian Kristiana (2018) yang menyatakan bahwa standar kompetensi berperan untuk memberikan pelayanan atau sevice officer dan dengan standar kompetensi yang baik akan memberikan pelayanan yang prima.

Menurut penelitian oleh Rusdi (2020) bahwa standar kompetensi memiliki pengaruh terhadap kualitas pelayanan yang diberikan perusahaan. Pelayanan yang prima merupakan pelayanan yang diharapkan oleh konsumen dan menjadi faktor terpenting untuk hubungan dengan konsumen dalam jangka waktu yang lama. Namun dalam optimalisasi mengenai standar kompetensi karyawan harus memenuhi syarat seperti skill, behavior, dan juga attidude yang baik. Dengan kualitas pelayanan yang baik maka akan terjalin hubungan jangka panjang konsumen terhadap perusahaan karena merasa puas dan sesuai harapan konsumen. Perusahaan pada sektor produk berbeda dengan perusahaan yang menawarkan jasa, dimana pada perusahaan jasa dituntut untuk memberikan pelayanan yang berkualitas sehingga harus mengoptimalkan bagian customer service nya untuk membentuk persepsi perusahaan yang baik di pikiran konsumen nya. Untuk mewujudkannya, karyawan perusahaan juga harus memiliki kemampuan maupun skil yang bagus seperti berpenampilan yang menarik, selalu siap untuk melayani konsumen, dan menangani berbagai keluhan yang diminta konsumen.

\section{PENUTUP}

\section{Kesimpulan}

Perusahaan pada sektor jasa membutuhkan kualitas sumber daya manusia yang harus diperhatikan, yang bertujuan untuk memberikan kepuasan pada konsumen. Sumber daya manusia berperan dalam menyampaikan penawaran tentang jasa perusahaannya kepada para klien atau pelanggan jasa.

Perusahaan pada sektor produk berbeda dengan perusahaan yang menawarkan jasa, dimana pada 
perusahaan jasa dituntut untuk memberikan pelayanan yang berkualitas sehingga harus mengoptimalkan bagian customer service nya untuk membentuk persepsi perusahaan yang baik di pikiran konsumen nya. Kompetensi merupakan karakterisitik yang menjadi dasar perilaku atas gambaran motif karakteristik pribadi dalam diri terhadap nilai mengenai pengetahuan yang memiliki kinerja yang unggul di dalam organisasi. Customer service merupakan orang-orang yang terlibat dalam perusahaan yang mampu mengembangkan pelayanan yang prima dan memberi perhatian kepada konsumen. Sedangkan Pelayanan juga bisa diartikan sebagai bentuk tindakan atau pertolongan yang ditujukan kepada konsumen baik secara langsung maupun tidak langsung dan yang berwujud maupun tidak berwujud.

Hasil penelitian yang dilakukan berdasarkan literatur terdahulu dan pendapat beberapa ahli yang diolah peneliti, hasilnya bahwa kompetensi memiliki peran yang sangat penting bagi customer service dalam meningkatkan pelayanan. Hal ini juga sejalan dengan penelitian Hutabalian (2015) yang haslnya bahwa customer service berperan penting untuk meningkatkan mutu layanan terhadap konsumen. Selain itu penelitian Kristiana (2018) yang menyatakan bahwa standar kompetensi berperan untuk memberikan pelayanan atau sevice officer dan dengan standar kompetensi yang baik akan memberikan pelayanan yang prima.

\section{Ucapan Terima kasih}

Terimakasih kepada dosen mata kuliah competency based human capital yang telah memberikan arahan dan saran untuk penelitian sehingga dapat lebih baik lagi dan pihak yang telah memberikan data untuk penelitian

\section{REFERENSI}

Alma, Buchari. (2016). Manajemen Pemasaran dan Pemasaran Jasa. Bandung: Alfabeta

Bilisaanika, H. N. F. (2019). Peranan Customer Service dalam meningkatkan kualitas pelayanan bandara Adi Soemarmo Boyolali.

Hutabalian, Y. H., \& Kalangi, J. S. (2015). Peran Customer Service dalam Meningkatkan Mutu Pelayanan di PT. Bank Rakyat Indonesia (Persero) Tbk Unit Politeknik. ACTA DIURNA KOMUNIKASI, 4(3).

Kasmir, 2017. Etika Customer Service, Manajemen Dana Bank Syariah PT.RajaGrafindo Persada, Jakarta

Kamir, 2017. Customer Service Excellent, Edisi Revisi. Jakarta : PT Raja Grapindo Persad

Krisni, D. N. (2016). Peranan Customer Service Dalam Meningkatkan Loyalitas Nasabah Penabung Pada Bank Muamalat Indonesia Kantor Cabang Pembantu Tulungagung.

Kotler, Philip and Kevin Lane Keller, (2016). Marketing Managemen, 15th Edition, Pearson

Education,Inc.

Moeheriono, 2015, Pengukuran Kinerja Berbasis Kompetensi Edisi Revisi,. Jakarta: PT RajaGrafindo Persada.

Nurjayanti, F., \& Widayati, R. (2019). Peranan Customer Service Dalam Operasional Bank Nagari Cabang Pekanbaru. 
Parasuraman, Valarie A. Zeithaml, and Leonard L. Berry. 2016. Pengaruh Promosi dan Kualitas Pelayanan Terhadap Kepuasan.

Pahlijan, R. R. (2017). Manajemen pelayanan prima dalam meningkatkan kualitas manajemen $\quad \mathrm{KBIH}: \quad$ Studi deskriptif di KBIH Bintaldam III/Siliwangi jln. Aceh no 69 Bandung (Doctoral dissertation, UIN Sunan Gunung Djati Bandung).

Rangkuti, F. (2017). Customer Service Satiscaction \& Call Centre Berdasarkan ISO 9001. Gramedia Pustaka Utama.

Rangkuti, F. (2017). Customer Care Excellence: Meningkatkan Kinerja Perusahaan Melalui Pelayanan Prima Plus Analisis Kasus Jasa Raharja. Gramedia Pustaka Utama.

Rusdi, M. (2020). Nilai Kompetensi Terhadap Kualitas Pelayanan Di Kecamatan Maritengngae Kabupaten Sidenreng Rappang.

Sadono Sukirno,2016. Pengantar Bisnis,(Jakarta: Prenada Media Group)

Sugiyono. (2016). Metode Penelitian Kuantitatif, Kualitatif dan R\&D. Bandung: PT Alfabet

Swiska, B. (2016). Peran Customer Service dalam Meningkatkan Pelayanan Penumpang Distasiun Solo Balapan Surakarta.

Tjiptono, Fandy. (2018). Strategi Pemasaran. Edisi 3. Yogyakarta : ANDI

Fandy, Tjiptono dan Greforius, Chandra. (2020). Pemasaran Jasa (Prinsip,.
Penerapan, dan Penelitian), Yogyakarta: And

Wibowo, 2016. Manajemen Kinerja, Edisi Kelima, PT.Rajagrafindo Persada. Jakarta-14240.

Widiawati, K. (2018), peran standar kompetensi karyawan sebagai upaya meningkatkan pelayanan prima pada bisnis perbankan di Indonesia. VOCATIO: Jurnal Ilmiah Ilmu Administrasi dan Sekretari, 1(2), 17-31

Winowatan, W., Suarta, I. P., \& Sukaran, M. (2020). Analisis Komeptensi Dalam Memaksimalkan Pelayanan Prima Pada Restoran Di Kabupaten Polewali Sulawesi Barat .Jurnal Ilmiah Manajemen Emor (Ekonomi Manajemen Orientasi Riset), 3(2), 119-135.

Wulandari, A. Y. (2016). Analisis Kompetensi Komunikasi Customer Service Dalam Meningkatkan Kepuasan Pelayanan Publik. Al-KALAM JURNAL KOMUNIKASI, BISNIS DAN MANAJEMEN, 2(2).. 
Dedi Rianto Rahadi, dan Alda Amelia Majid, Kompetensi Peran Customer Service dalam Mendukung Pelayanan Kepada Konsumen... 